\title{
The effect of human capital, structural capital, customer capital, managerial ownership, and leverage toward profitability of company
}

\author{
${ }^{1}$ Tia Maharani, ${ }^{1}$ Khoirul Fuad* \\ Accounting, Economic Faculty, Universitas Islam Sultan Agung, Indonesia
}

*Corresponding Author

Email: khoirulfuad@unissula.ac.id

Received:

4 June 2020
Revised:

21 July 2020
Accepted:

31 July 2020
Published:

31 July 2020

\begin{abstract}
Profitability is the ability of a company to generate profits. In an effort to achieve profitability, companies must be able to convert and be able to combine the necessary resources effectively and efficiently. These efforts can help in increasing profits earned by the company. One of the factors that can determine the good or bad performance of a company is profit, because of profit The purpose of this study is to study and analyze the influence of Human Resources, Structural Capital, Customer Capital, Good Governance and influence on Company Profitability. The population in this study were manufacturing companies listed on the Indonesia Stock Exchange from 2015 to 2017. The samples obtained by purposive sampling technique were 38 companies. The technique of taking data was by getting secondary data from IDX. The results of research using multiple regression analysis are: Human resources have no significant negative effect on profitability. Structural capital has a significant positive effect on profitability. Customer capital has a significant positive effect on profitability. Ownership is negative about profitability. Leverage has a significant negative effect on profitability.
\end{abstract}

Keywords: Human Capital; Structural Capital; Customer Capital; Managerial Ownership; Leverage; Profitability

\section{INTRODUCTION}

Profitability is the ability of a company to generate profits. In an effort to achieve this profitability, companies must be able to operate smoothly and be able to combine their resources effectively and efficiently. These efforts can help in increasing the profit earned by the company. One of the factors that can determine the good or bad performance of a company is profitability, because the profitability of a company affects the company's survival (Pratiwi, 2018). Changing the growth base of the company from a labor-based business to a knowledge-based business will create a way to manage knowledge as a means to improve company performance (Pratiwi, 2018). This is better known as the company's intellectual capital (IC).

According to Pulic (2008) in Barokah et al, (2018), the way companies compete is by changing the way they run their business, which was originally based on working manually towards a knowledge-based business in order to find out how to use resources 
Maharani, T., \& Fuad, K. (2020). The effect of human capital, structural capital, customer capital, managerial ownership, and leverage toward profitability of company. Journal of Advanced Multidisciplinary Research, 1 (1), 46-62. DOI: http://dx.doi.org/10.30659/JAMR.1.1.46-62

more efficiently and economically. will provide an edge for the company. This has resulted in intellectual capital becoming one of the important sources of company assets because it contains an important element, namely knowledge.

Profitability is the company's ability to get profit within a certain period (Putra, 2017). One of the ratio analyzes that companies use in assessing the company's financial performance is the profitability ratio (Pratiwi, 2018). Profitability has a very important role in the structure and development of the company because it can measure performance (Putra, 2017). If the company is able to make a lot of sales, it has a greater opportunity to increase profitability (Sari, 2019). This study uses a profitability proxy in the form of the value of Return on Assets (ROA).

Human capital is an important part of IC for the advancement of a company in the future and will be used as a determining factor to assess the company's performance in the future. Human Capital is a combination of genetic inheritance which includes education, experience, and behavior about life and business (Putra, 2017). If the company is able to treat its employees as capital rather than as a resource, the company will gain an advantage. This human capital will later support other IC components, namely structural capital and customer capital. This is in accordance with research conducted (Putra, 2017) which states that Human Capital has a significant effect on profitability (ROA), while the research conducted (Rousiita, 2012) states that Human Capital has no effect on profitability (ROA).

According to Starovic (2004), Structural Capital is the knowledge that remains in the company that gives the company the ability to fulfill the company's routine processes and its structure that supports employees' efforts to produce optimal intellectual performance and overall business performance. Every individual in it can have a high level of intellectuality, but if the organization has bad systems and procedures, IC cannot achieve optimal performance and the existing potential cannot be maximally utilized (Widiatmoko in Putra et al, 2017). Putra (2017) states that structural capital has a significant positive effect on company profitability, whereas according to Pradwita (2008), Structural Capital has no effect on company profitability.

Customer capital is the potential of an organization that is not tangible from the company (Aritonang et al, 2016). This definition of capital has been developed by including relational capital which is knowledge embedded in all organizational relationships from customers, competition, suppliers, trade associations or from the government (Bontis in Aritonang et al, 2016). It can be said that the better the relationship, the greater the opportunity for the company to learn with its customers and suppliers (Putra, 2017). According to Reza (2015), Customer Capital has a significant positive effect on company profitability, while the statement made according to (Putra, 2017) states that Customer Capital has no effect on company profitability.

Good Corporate Governance (GCG) is a form of good company management, which includes a form of protection for shareholders (public) as company owners and creditors as external funders (Badawi, 2018). Good Corporate Governance is still a challenge for companies to implement. However, in order for financial sector companies to have healthy financial performance, it is still necessary to implement Good Corporate Governance (Kartikasari, 2017). The implementation of GCG can encourage the creation of healthy competition and a conducive business atmosphere (Putra, 2017). 
Journal of Advanced Multidisciplinary Research

Vol. 1, No. 1, 2020, pp. 46-62

ISSN: $2723-6978$

http://jurnal.unissula.ac.id/index.php/JAMR

DOI: http://dx.doi.org/10.30659/JAMR.1.1.46-62

According to Wilopo (2011), Good Corporate Governance has a significant positive effect on company profitability, meanwhile according to research conducted (Putra, 2017) states that Good Corporate Governance has no significant effect on company profitability.

Leverage is a measure of how much a company uses capital and debt to finance its assets (Enekwe et al, 2014). Companies whose funding comes mostly from debt will receive benefits in the form of reduced debt interest on the calculation of taxable income to reduce the proportion of the tax burden so that the proportion of net income becomes bigger or the level of profitability is getting higher (Sartono in Sari \& Dwirandra, 2019).

The company in achieving its goals requires additional funds to facilitate the course of company activities. Companies can generate sources of funds from outside the company in the form of debt or share issuance (Ikhsani et al, 2016). This study uses a leverage proxy in the form of the value of the Debt to Equity Ratio (DER). According to Umi (2013), leverage does not have a significant negative effect on company profitability. Meanwhile, Dewi (2017) states that leverage has a positive effect on company profitability.

This research refers to the research of Putra (2017). The difference between this study and previous research is that it lies in 1) Year of research: In the previous study, the year used was 2012-2015, while in this study, it was 2015-2017, 2) the sample of companies: Previous research used banking companies, while this current research is the sector manufacturing, and 3) the addition of a variable, namely leverage. This leverage variable can show the ability of own capital to fulfill all of its obligations.

Based on the explanation above, the researcher is interested in conducting research on the influence of Human Capital, Structural Capital, Customer Capital, Good Corporate Governance, and Leverage on Company Profitability: An Empirical Study of Manufacturing Sector Companies Listed on the Indonesia Stock Exchange (IDX) for the 2015 Period -2017. This study aims to: (1) test and analyze the effect of Human Capital on Company Profitability, (2) test and analyze the effect of Structural Capital on Company Profitability, (3) test and analyze the effect of Customer Capital on Company Profitability, (4) test and analyze the effect of Good Corporate Governance on Company Profitability, and (5) testing and analyzing the effect of Leverage on Company Profitability.

\section{Stakeholder Theory}

The theory that supports this research is the Stakeholder Theory. According to Chariri \& Ghozali (2007), Stakeholder Theory is a theory which states that a company is not an entity that only operates for its own interests, but must provide benefits to all its stakeholders (shareholders, creditors, consumers, suppliers, government, society, analysts, etc. and other parties). This stakeholder group becomes a consideration for company management in disclosing whether or not the information in the company report is made.

The main objective of stakeholder theory is to assist company management in increasing value creation as a result of the activities carried out and minimizing any losses that may arise for stakeholders. The concept of intellectual capital contained in stakeholder theory can be viewed in 2 fields, namely the ethical (moral) field and the managerial field. Ethics states that all stakeholders have the right to be treated fairly by the company and managers must manage company profits for the benefit of all 
Maharani, T., \& Fuad, K. (2020). The effect of human capital, structural capital, customer capital, managerial ownership, and leverage toward profitability of company. Journal of Advanced Multidisciplinary Research, 1 (1), 46-62. DOI: http://dx.doi.org/10.30659/JAMR.1.1.46-62

stakeholders (Ulum, 2009). When managers can manage the company optimally, especially in managing value creation, this means that they have fulfilled the ethical field of stakeholder theory (Ulum, 2009). Good management of all the potential of the company can create added value for the company which is able to encourage the company's financial performance for the benefit of stakeholders.

Whereas in the managerial field, stakeholder theory states that the ability of stakeholders to influence management must be seen as a function of the level of stakeholder control over the resources needed by the company (Ulum, 2009). When stakeholders seek to control company resources, control over resources can be focused on improving the welfare of stakeholders. This welfare can be realized in the higher returns generated by the company (Ulum, 2009).

The relationship between profitability and stakeholders in this study is a group or individual who can influence and be responsible for the existence of a company. If the stakeholders are successful in increasing their profitability, it will ease them to generate profits.

\section{METHOD}

The type of data used in this research is secondary data, while the research design used is quantitative design. The quantitative method is a scientific approach to managerial and economic decision making (Kuncoro, 2007). The data used in this study comes from the financial statements of manufacturing companies listed on the Indonesia Stock Exchange (IDX) for the period 2015 to 2017.

The population used in this study were manufacturing companies listed on the Indonesia Stock Exchange for the period 2015 to 2017. While the determination of the sample in this study used purposive sampling technique, which is a sampling technique based on certain criteria. The criteria used in determining the sample of this study are (1) manufacturing companies that publish annual financial reports during 2015-2017 in rupiah (IDR), (2) manufacturing companies that generated consecutive profits during 2015-2017, and (3) manufacturing companies that report complete financial statements whose financial reporting period ended on December 31 during 2015-2017.

\section{Kinds of data sources}

The type of data used in this research is quantitative data. Quantitative data is data that is measured on a numerical scale such as the numbers listed in the company's financial statements. While the data source used in this study is secondary data. According to Sugiyono (2016), secondary data is data that does not directly provide data to researchers, such as data that must be obtained using literature studies conducted on many books and obtained based on records related to research and using data obtained from the internet. Secondary data in this study are the financial statements of manufacturing companies listed on the Indonesia Stock Exchange for the period 2015 to 2017 through the website (www.idx.co.id).

\section{Data collection method}

The data is collected by using literature and documentation methods. The literature method is carried out by studying the literature and related research to obtain a strong research basis and can solve research problems. While the documentary method is 
Journal of Advanced Multidisciplinary Research

Vol. 1, No. 1, 2020, pp. 46-62

ISSN: $2723-6978$

http://jurnal.unissula.ac.id/index.php/JAMR

DOI: http://dx.doi.org/10.30659/JAMR.1.1.46-62

carried out by finding and collecting company financial report data from the website (www.idx.co.id) and related research websites.

\section{Variable and indicator}

The variables used in this study consisted of 2 variables, namely the dependent variable and the independent variable. The dependent variable is profitability. The independent variables are human capital, structural capital, customer capital, good corporate governance and leverage. Profitability is a measurement of the company's ability to generate or increase profits. Profitability can reflect the level of effectiveness achieved by a company. According to Suryani (2011) bank profitability is a bank's ability to produce in a period. A healthy bank is a bank that is measured in terms of profitability which continues to increase above the set standard.

Profitability is measured using the return on asset ratio (ROA), which connects the profits obtained from the main activities or activities of the company with the assets owned to generate revenue and profits for the company. Return on assets (ROA) is an indicator of a company's success in generating profits, so that the higher the profitability, the higher the company's ability to generate profits (Rachmawati, 2012).

The first independent variable is the human capital ratio, which is used to show how much value added (VA) can be generated with the funds spent on labor. This ratio also shows that the contribution made by each rupiah invested in human capital to the organization's added value. The second independent variable is the structural capital ratio which is used to measure the amount of structural capital (SC) needed to produce one rupiah from Value Added (VA) and is an indication of how successful Structural Capital (SC) is in value creation. The third independent variable is the customer capital ratio. It shows the contribution made by each unit of Capital Employed (CE) to the organization's Value Added. Value Added (VA) is the most objective indicator used to assess the success of a company and can show its ability to create value (Value Creation). The fourth independent variable is good corporate governance. In this study, the authors used one indicator, namely managerial ownership measured by the percentage of shares owned by the manager (Putra, 2017). The fifth independent variable is leverage. According to Syamsudin (2001), leverage is usually used to describe a company's ability to use fixed cost assets or funds to increase the rate of return for company owners. The proportion of leverage (LEV) is measured by the ratio of total debt to total assets. The proportion of leverage is expressed in percentages (Samani, 2008).

\section{Data Analysis Technique}

The data analysis technique used in this study is multiple regression analysis. The stages of testing in conducting data analysis are to conduct testing starting from the descriptive statistical test used to describe the collected sample data before using statistical analysis techniques that function to test hypotheses. Descriptive statistics in this study are used to disclose company characteristics and good corporate governance in manufacturing companies listed on the IDX in 2015-2017.

Considering that the research data used is secondary, in order to fulfill the conditions determined before multiple linear regression testing, it is necessary to test several classical assumptions. Multiple linear regression analysis needs to avoid 
Maharani, T., \& Fuad, K. (2020). The effect of human capital, structural capital, customer capital, managerial ownership, and leverage toward profitability of company. Journal of Advanced Multidisciplinary Research, 1 (1), 46-62. DOI: http://dx.doi.org/10.30659/JAMR.1.1.46-62

deviating classical assumptions so that problems do not arise using the analysis (Ghozali, 2013). The tests used are normality, multicollinearity, autocorrelation and heteroscedasticity. In addition, the Model Goodness Test and Hypothesis Test are also used.

\section{RESULTS AND DISCUSSION \\ Research object overview}

A manufacturing company is a business entity that operates machinery, equipment and labor in a process medium to convert raw materials into finished goods that have a selling value. The manufacturing industry is divided into several types of companies engaged in fields such as basic and chemical industries, various industries, and various consumer goods. The reason for using a manufacturing company in this study is that the number of manufacturing companies has a large number of companies on the Indonesia Stock Exchange, besides manufacturing companies have a lot of human resources. Therefore they need intellectual capital in managing these human resources in order to compete with similar companies.

This study takes the population of manufacturing companies listed on the Indonesia Stock Exchange (BEI) from 2015 to 2017 respectively which were obtained from the website http: /www.idx.co.id. The sample in the study was a manufacturing company on the IDX in 2015-2017 with the following sample criteria:

Table 1.

Sampling technique criteria

\begin{tabular}{clc}
\hline No. & \multicolumn{1}{c}{ Notes } & Amount of company \\
\hline & Manufacturing companies listed in & 146 companies \\
1 & BEI during 2015-2017 & 25 companies \\
\hline 2 & $\begin{array}{l}\text { They have no financial reports per 31 } \\
\text { December tahun 2015-2017 }\end{array}$ & 29 companies \\
\hline 3 & Financial repotrs in dollar & 54 companies \\
\hline 4 & $\begin{array}{l}\text { They have no complete data for research } \\
\text { (Managerial ownership) }\end{array}$ & 38 companies \\
\hline 5 & Yearly Research sample & 114 companies \\
\hline 6 & Sample for 3 years & \\
\hline
\end{tabular}

From table 1, it is obtained that the research sample with predetermined criteria is 38 manufacturing companies that go public in the Indonesia Stock Exchange. With the pooled crosectional processing system, the amount of data processed was $38 \times 3$ years of research, namely 114 data.

\section{The description of research variable}

Descriptive statistics will suggest ways of presenting research data. The description of the data is accompanied by the minimum value, maximum value, mean and standard deviation. The number of samples was 38 companies with a time series system for 3 consecutive years in 2015-2017, with 114 data processed. The following is a descriptive statistic of 114 research data consisting of the variables of human capital, structural capital, customer capital, managerial ownership and leverage. 
Table 2. Descriptive statistics

\begin{tabular}{lrrrrr}
\hline & N & Minimum & Maximum & Mean & $\begin{array}{r}\text { Std. Dev iat } \\
\text { ion }\end{array}$ \\
\hline Human Capital & 114 & 4.1266 & 90.5181 & 26.917410 & 19.3369606 \\
Structural Capital & 114 & .7577 & .9890 & .939571 & .0443485 \\
Customer Capital & 114 & 51807 & 126734000 & 10323991.22 & 24156125.104 \\
Kepemilikan Manajerial & 114 & .01 & 83.95 & 10.4595 & 18.81075 \\
Leverage & 114 & .0848 & .9104 & .454438 & .1983027 \\
Prof itabilitas & 114 & -.0971 & .2615 & .029557 & .0615982 \\
Valid N (list wise) & 114 & & & & \\
\hline
\end{tabular}

Table 2 shows the descriptive statistical value of each research variable, the explanation of each variable is described as follows:

\section{Human Capital}

The human capital variable shows that the number of data (n) is 114 , while the mean value is 26.917 and the minimum value is 4.126 , while the maximum value is 90.51 . The standard deviation value of human capital data is 19.33 , smaller than the mean of 26.917, thus the data distribution for human capital variables in this study is evenly distributed, meaning that there is no high difference between one data and another.

\section{Structural Capital}

The variable structural capital shows that the number of data (n) is 114 , while the mean value is 0.9395 and the minimum value is 0.7577 , while the maximum value is 0.9890 . The standard deviation value for structural capital is 0.0443 , which is smaller than the mean of 0.9395 , thus the data distribution for the structural capital variable in this study is evenly distributed, meaning that there is no high difference between one data and another.

\section{Customer Capital}

The customer capital variable shows that the number of data (n) is 114 , while the mean value is 10323991.22 and the minimum value is 51807 , while the maximum value is 126734000.The standard deviation value for customer capital is 24156125.104, greater than the mean of 10323991.22, thus the distribution of data for customer capital variables in this study is not evenly distributed, meaning that there is a high difference between one data and another.

\section{Managerial Ownership}

Managerial ownership shows that the number of data (n) is 114, while the mean value of managerial ownership as measured by the number of shares owned by managerial shares of the total outstanding shares of the companies sampled in this study is 10.45 percent, with a minimum value of 0.01 percent. , and the maximum value is 83.95 percent. The standard deviation value of managerial ownership is 18.81 , greater than the mean of 10.45, thus the distribution of data for managerial ownership variables in this study is unevenly distributed, meaning that there is a fairly high difference between one 
Maharani, T., \& Fuad, K. (2020). The effect of human capital, structural capital, customer capital, managerial ownership, and leverage toward profitability of company. Journal of Advanced Multidisciplinary Research, 1 (1), 46-62. DOI: http://dx.doi.org/10.30659/JAMR.1.1.46-62

data and another.

\section{Leverage}

The leverage variable shows that the number of data (n) is 114 , while the mean value as measured by the asset debt of the sample companies is 0.4544 or 45.44 percent, meaning that every rupiah of assets is used to guarantee a debt of Rp. 0.4544 and the minimum value is 0.0848 or 8.48 percent, and the maximum value is 0.9104 or 91.04 percent. The standard deviation value of leverage is 0.1983 , smaller than the mean of 0.4544 , thus the data distribution for the leverage variable in this study is evenly distributed, meaning that there is no high difference between one data and another.

\section{Profitability}

The profitability variable shows that the number of data (n) is 114 , while the mean value of profitability as measured by the return on assets of the sample companies is 0.02955 or 2.95 percent, meaning that every rupiah of the assets used can generate a profit of Rp. 0.02955 . The minimum value is -0.0971 or -9.71 percent, and the maximum value is 0.2615 or 26.15 percent. The standard deviation value of profitability is 0.06159 , greater than the mean of 0.02955 , thus the distribution of data for profitability variables in this study is unevenly distributed, meaning that there is a high difference between one data and another.

\section{Data Analysis \\ Classic assumption test \\ Data Normality}

Data normality can be used to test whether the regression model, the independent variable and the dependent variable are both normally distributed or not. In this study, the data normality test used the one sample Kolmogorov-Smirnov Test. The results of the data normality test used 114 data as follows:

Table 3.

Normality Test

\begin{tabular}{llr}
\hline & & \multicolumn{1}{c}{ Unstandardi } \\
zed Residual
\end{tabular}

Based on the results of table 3 above, the significant value of Kolmogorov Smirnov is $0.299<0.05$, thus the regression model in this study has met the normality assumption and it can be concluded that the data is normally distributed. 


\section{Multicollinearity Test}

Multicollinearity test is used to test whether the regression model finds a relationship between the independent variables. If there is a correlation, it means that it has multicollinearity problems. A good regression model should not have a correlation between the independent variables. The multicollinearity symptom is carried out to test the presence or absence of the correlation matrix value obtained during data processing as well as the VIF (Variance Inflation Factor) and Tolerance values.

The value of VIF $<10$ and tolerance $>0.1$, indicates that there is no multicollinearity symptom. The multicollinearity test results can be seen in table 4 .

Table 4.

Multicollinearity Test

\begin{tabular}{llrc}
\hline \multirow{2}{*}{ Model } & \multicolumn{2}{c}{ Collinearity } & Statistics \\
\cline { 3 - 4 } & & Tolerance & VIF \\
\hline 1 & Human Capital & .505 & 1.981 \\
& Structural Capital & .523 & 1.911 \\
& LNCustomer Capital & .798 & 1.253 \\
& Kepemilikan Manajerial & .859 & 1.164 \\
& Leverage & .954 & 1.048 \\
\hline
\end{tabular}

The results of the data from the SPSS calculation in table 4 show that the VIF (Variance Inflation Factor) value of each independent variable (human capital, structural capital, customer capital, managerial ownership and leverage) is less than 10 and the tolerance value is more than 0.1 with Thus it can be interpreted that the regression model in this study did not occur multicollinearity symptoms.

\section{Autocorrelation Test}

The autocorrelation test is used to test whether the regression model has a correlation with the confounding error in period $t$ with an error in period $t-1$ (previous). The autocorrelation test was carried out using the Durbin Watson (DW) mapping test.

Table 5.

Autocorrelation Test

\begin{tabular}{lc}
\hline Model & $\begin{array}{l}\text { Durbin- } \\
\text { Watson }\end{array}$ \\
\hline 1 & 1.858 \\
\hline
\end{tabular}

Based on table 5 above, autocorrelation detection can be done with the following test criteria (Gozali, 2013):

$$
\begin{aligned}
& \mathrm{du}<\mathrm{DW}<4-\mathrm{du} \\
& 1,780<1,858<4-1,780 \\
& 1,780<1,858<2,220
\end{aligned}
$$

Based on the results of the SPSS data in table 5 above, it can be explained that if the DW in the regression model $=1.858$, located before du (1.780) and after 4-du $(2,220)$, 
Maharani, T., \& Fuad, K. (2020). The effect of human capital, structural capital, customer capital, managerial ownership, and leverage toward profitability of company. Journal of Advanced Multidisciplinary Research, 1 (1), 46-62. DOI: http://dx.doi.org/10.30659/JAMR.1.1.46-62

then the regression equation model proposed has no autocorrelation with the DW category is smaller from 4-du and greater than du.

\section{Heteroscedasticity Test}

This heteroscedaticity test is used to test whether a regression model has a variance difference from the residuals of one observation to another. If the residual variance from one observation to another is constant, it is called homoscedasticity, and if it experiences a difference it is called heteroscedasticity. A good regression model is that there is no heteroscedasticity.

Heteroscedasticity testing is done by looking at the statistical value of the Glacier test, if the significance value of each independent variable is more than 0.05 , this indicates no heteroscedasticity. The results of the heteroscedasticity test are as follows:

Table 6.

Heteroscedasticity Test

\begin{tabular}{|c|c|c|c|c|c|c|}
\hline & & Coeffic & $n \mathbf{n s}^{\mathrm{a}}$ & & & \\
\hline \multirow[b]{2}{*}{ Model } & & \multicolumn{2}{|c|}{$\begin{array}{l}\text { Unstandardized } \\
\text { Coeff icients }\end{array}$} & \multirow{2}{*}{$\begin{array}{l}\text { Standardized } \\
\text { Coeff icients } \\
\text { Beta }\end{array}$} & \multirow[b]{2}{*}{$t$} & \multirow[b]{2}{*}{ Sig. } \\
\hline & & $\mathrm{B}$ & Std. Error & & & \\
\hline \multirow[t]{6}{*}{1} & (Constant) & -.100 & .104 & & -.967 & .336 \\
\hline & Human Capital & .000 & .000 & -.144 & -1.084 & .281 \\
\hline & Structural Capital & .173 & .111 & .203 & 1.560 & .122 \\
\hline & LNCustomer Capital & .000 & .002 & -.023 & -.220 & .826 \\
\hline & Kepemilikan Manajerial & .000 & .000 & -.071 & -.698 & .487 \\
\hline & Leverage & -.027 & .018 & -.140 & -1.451 & .150 \\
\hline
\end{tabular}

a. Dependent Variable: Abs_res

Based on table 6, it can be explained that the significance value obtained from each variable, namely human capital, structural capital, customer capital, managerial ownership and leverage is greater than 0.5 . Thus it can be concluded that the regression model does not occur heteroscedasticity.

\section{Multiple Regression}

\section{Multiple Regression Equation}

The results of the regression equation on the effect of human capital, structural capital, customer capital, managerial ownership and leverage can be seen in the following table.

Table 7.

Multiple Regression Equation

\begin{tabular}{|c|c|c|c|c|c|c|}
\hline \multirow[b]{2}{*}{ Model } & & \multicolumn{2}{|c|}{$\begin{array}{l}\text { Unstandardized } \\
\text { Coeff icients }\end{array}$} & \multirow{2}{*}{$\begin{array}{c}\begin{array}{l}\text { Standardized } \\
\text { Coeff icients }\end{array} \\
\text { Beta }\end{array}$} & \multirow[b]{2}{*}{$\mathrm{t}$} & \multirow[b]{2}{*}{ Sig. } \\
\hline & & $\mathrm{B}$ & Std. Error & & & \\
\hline \multirow[t]{6}{*}{1} & (Constant) & -.464 & .136 & & -3.411 & .001 \\
\hline & Human Capital & -.001 & .000 & -.210 & -1.960 & .053 \\
\hline & Structural Capital & .435 & .146 & .313 & 2.976 & .004 \\
\hline & LNCustomer Capital & .012 & .003 & .397 & 4.658 & .000 \\
\hline & Kepemilikan Manajerial & -.001 & .000 & -.163 & -1.990 & .049 \\
\hline & Leverage & -.133 & .024 & -.428 & -5.498 & .000 \\
\hline
\end{tabular}


From Table 7, from the results of data processing with the help of the SPSS program, the final regression equation model is obtained as follows:

$$
\mathrm{Y}=-0.464-0.001 \mathrm{X} 1+0.435 \mathrm{X} 2+0.012 \mathrm{X} 3-0.001 \mathrm{X} 4-0.133 \mathrm{X} 5+\mathrm{e}
$$

The meaning of the regression equation above is as follows:

a. The results obtained from the multiple regression calculation with a constant value of -0.464 , are negative, so it can be interpreted that if human capital, structural capital, customer capital, managerial ownership and leverage are fixed or constant, then the profitability is $-0.464 \%$.

b. The results obtained from the value of the human capital regression coefficient are negative of -0.001 , meaning that if human capital has increased by $1 \%$, then profitability will decrease by $0.001 \%$.

c. The results obtained from the structural capital regression coefficient are positive at 0.435 , meaning that if structural capital has increased by $1 \%$, then the profitability will increase by $0.435 \%$.

d. The results obtained from the regression coefficient value of customer capital are positive at 0.012 , meaning that if customer capital has increased by $1 \%$, then profitability will increase by $0.012 \%$.

e. The results obtained from the value of the managerial ownership regression coefficient are negative at -0.001 , meaning that if managerial ownership has increased by $1 \%$, then profitability will decrease by $0.001 \%$.

f. The results obtained from the value of the leverage regression coefficient are negative at -0.133 , meaning that if the leverage has increased by $1 \%$, then the profitability will decrease by $0.133 \%$.

\section{Goodness of Fit}

This test aims to determine whether human capital, structural capital, customer capital, managerial ownership and leverage have an effect on profitability. The results of this test can be seen in table 8 below.

Table 8. F Test

\begin{tabular}{llrrrrr}
\hline \multirow{2}{*}{ Model } & & $\begin{array}{c}\text { Sum of } \\
\text { Squares }\end{array}$ & df & Mean Square & F & Sig. \\
\hline 1 & Regression & .161 & 5 & .032 & 12.960 & .000 \\
& Residual & .268 & 108 & .002 & & \\
& Total & .429 & 113 & & & \\
\hline
\end{tabular}

Based on the results of the SPSS processing in table 8 above, it shows that the regression model testing obtained an F-count value of 12,960 and a significance value of 0,000 . So sig $F(0.000)<\alpha(0.05)$, it can be concluded that together the variables of human capital, structural capital, customer capital, managerial ownership and leverage have an effect on profitability. Thus the regression model in research is feasible for research. 
Maharani, T., \& Fuad, K. (2020). The effect of human capital, structural capital, customer capital, managerial ownership, and leverage toward profitability of company. Journal of Advanced Multidisciplinary Research, 1 (1), 46-62. DOI: http://dx.doi.org/10.30659/JAMR.1.1.46-62

\section{Coefficient of Determination}

The coefficient of determination aims to show how much the independent variable can explain the dependent variable expressed in percent $(\%)$. The test results are as follows:

Table 9. Coefficient of Determination

\begin{tabular}{lrrrr}
\hline Model & R & R Square & $\begin{array}{c}\text { Adjusted } \\
\text { R Square }\end{array}$ & $\begin{array}{r}\text { Std. Error of } \\
\text { the Estimate }\end{array}$ \\
\hline 1 & .612 & .375 & .346 & .0498121 \\
\hline
\end{tabular}

Based on the results of SPSS processing in table 9 above, it shows that the coefficient of determination as indicated by the adjusted $\mathrm{R}$ square value is 0.346 . This means that the independent variables (human capital, structural capital, customer capital, managerial ownership and leverage) can explain the dependent variable (profitability) of $34.60 \%$, while the rest is explained by other variables not observed in this study, such as institutional ownership, liquidity, and others.

\section{Hypothesis test}

Hypothesis testing in this study will be carried out by using partial testing of each independent variable on the dependent variable as follows:

Table 10. Hypothesis Test Results

\begin{tabular}{llll}
\hline \multicolumn{1}{c}{ Influence between variables } & $\begin{array}{c}\text { Beta } \\
\text { (coefficient) }\end{array}$ & Sig. t & Result \\
\hline Human Capital $\rightarrow$ Profitability & $-0,001$ & 0,053 & H1 rejected \\
\hline Structural Capital $\rightarrow$ Profitability & 0,435 & 0,004 & H2 accepted \\
\hline Customer Capital $\rightarrow$ Profitability & 0,012 & 0,000 & H3 accepted \\
\hline $\begin{array}{l}\text { Managerial Ownership } \rightarrow \\
\text { Profitability }\end{array}$ & $-0,001$ & 0,049 & H4 accepted \\
\hline Leverage $\rightarrow$ Profitability & $-0,133$ & 0,000 & H5 accepted \\
\hline
\end{tabular}

\section{Hypothesis Test of Human Capital}

Based on table 10 above, it can be seen that the partial test of human capital has a negative and insignificant effect on profitability, this can be proven by the regression coefficient value of -0.001 and a significance value of $0.053>0.05$. Thus, the hypothesis which states that human capital has a positive effect on profitability is rejected, meaning that the size of human capital has no effect on the size of the profitability.

\section{Hypothesis Test of Structural Capital}

Based on table 10, it can be seen that the partial test of structural capital has a significant positive effect on profitability, this is evidenced by the regression coefficient value of 0.435 and a significance value of $0.004<0.05$. Thus the hypothesis which states that structural capital has a positive effect on profitability is acceptable, meaning that the greater the value of structural capital, the higher the level of profitability and vice versa. 


\section{Hypothesis Test of Customer Capital}

Based on table 10 above, it can be seen that the partial test of customer capital has a significant positive effect on profitability, this is evidenced by the regression coefficient value of 0.012 and a significance value of $0.000<0.05$. Thus the hypothesis which states that customer capital has a positive effect on profitability is acceptable, meaning that the greater the customer capital, the higher the level of profitability and vice versa.

\section{Hypothesis Test of Managerial Ownership}

Based on table 10 above, it can be seen that partially testing managerial ownership has a significant negative effect on profitability, this is evidenced by the regression coefficient value of -0.001 and a significance value of $0.049<0.05$. Thus the hypothesis which states that managerial ownership has a negative effect on profitability is accepted, meaning that the greater the value of managerial ownership, the lower the level of profitability.

\section{Hypothesis Test of Leverage}

Based on table 10 above, it can be seen that the partial test of leverage has a significant negative effect on profitability, this is evidenced by the regression coefficient value of 0.133 and a significance value of $0.000<0.05$. Thus the hypothesis which states that leverage has a negative effect on profitability is acceptable, meaning that the greater the leverage value, the lower the level of profitability.

\section{Discussion}

\section{Pengaruh Human Capital Terhadap Profitabilitas}

Human capital has a negative and insignificant effect on profitability. This condition occurs because human resource management without being followed by improvements and efficiency in the company will not result in increasing profits. In addition, increasing human capital will not necessarily provide good profitability because in managing human capital, it must be adjusted to the competence of human resources owned, and the competition factors of similar companies.

This result does not support the stakeholder theory which states that companies working not only for their own interests but also for the benefit of all stakeholders, such as increasing human capital will increase the company's profitability. This condition occurs because increasing profitability for the interests of stakeholders can not only be done by increasing human capital, there are still many other factors that influence the company's profitability to increase, both internal factors such as capital, products as well as external factors such as market conditions, competition with competitors and macroeconomics (inflation, government policies).

These results support the research of Suhendah and Rousilita (2012), which states that human capital has a negative effect on profitability.

\section{The Influence of Structural Capital on Profitability}

Structural capital has a significant positive effect on profitability. This condition occurs because the higher the structural capital, it will have an impact on an efficient production process and is able to reduce unwanted production costs, so that it will increase the company's profit from assets. This result is in accordance with the 
Maharani, T., \& Fuad, K. (2020). The effect of human capital, structural capital, customer capital, managerial ownership, and leverage toward profitability of company. Journal of Advanced Multidisciplinary Research, 1 (1), 46-62. DOI: http://dx.doi.org/10.30659/JAMR.1.1.46-62

stakeholder theory which states that companies that are able to manage organizational resources properly will create a competitive advantage. By emphasizing the company's ability and structure that supports employees' efforts to produce optimal intellectual performance and overall business performance, thereby increasing profits. The results of this study support Kuspinta's (2018) research which states that structural capital has a positive effect on profitability.

\section{The Influence of Customer Capital on Profitability}

Customer capital has a significant positive effect on profitability. This condition occurs because the higher the customer capital, the better and more competitive the management of human resources and knowledge will be, so that the company is able to improve company performance by maximizing sales and capital use, and increasing profits. These results support the stakeholder theory, which states in order to increase the company's interests, while the increase in sales that occurs is due to the harmonious relationship the company has with its partners, both from reliable and quality suppliers, from loyal customers who are satisfied with the service. the company concerned, comes from the company's relationship with the government and with the surrounding community. The results of this study support Kuspinta's (2018) research which states that customer capital has a positive effect on profitability.

\section{The Effect of Managerial Ownership on Profitability}

Managerial ownership has a significant negative effect on profitability. This condition occurs because the higher managerial ownership, the more opportunistic behavior of management will be, this will have a negative impact on company performance, so that profitability will decrease. This result supports the stakeholder theory, which states that managerial work should also pay attention to the interests of stakeholders, not just their own interests. If managerial levels are higher, opportunistic behavior will increase and company performance will get worse. The results of the study which show that managerial ownership has a significant negative effect on profitability supports Hamidah's (2013) research which states that managerial ownership has a negative effect on profitability.

\section{Effect of Leverage on Profitability}

Leverage has a significant negative effect on profitability. This condition occurs because leverage is an important issue in making decisions about company spending. Company leverage describes the ratio between total debt and assets. The greater this ratio indicates that the greater the capital structure that comes from debt is used to finance existing assets, so that the profit generated by the company will decrease. These results support the stakeholder theory, which states that in working with the interests of stakeholders, improper selection of the capital structure of debt will make the company suffer losses and this will make the company's performance worse. This will reduce the company's performance. These results support Hamidah's (2013) research, proving that leverage has a negative effect on profitability.

\section{CONCLUSION}


Journal of Advanced Multidisciplinary Research

Vol. 1, No. 1, 2020, pp. 46-62

ISSN: $2723-6978$

http://jurnal.unissula.ac.id/index.php/JAMR

DOI: http://dx.doi.org/10.30659/JAMR.1.1.46-62

Based on the results of the research that has been done, several conclusions can be made. Human capital has a negative and insignificant effect on profitability. This condition occurs because human resource management without being followed by improvements and efficiency in the company will not result in increasing profits. In addition, increasing human capital will not necessarily provide good profitability because in managing human capital, it must be adjusted to the competence of human resources owned, and the competition factors of similar companies.

Structural capital has a significant positive effect on profitability. This condition occurs because the higher the structural capital, it will have an impact on an efficient production process and is able to reduce unwanted production costs, so that it can increase the company's profit from assets, so if the structural capital is managed properly it will increase the profit from the company's assets.

Customer capital has a significant positive effect on profitability. This condition occurs because the higher the customer capital, the better and more competitive the management of human resources and knowledge will be, so that the company is able to improve company performance by maximizing sales and capital use, and increasing profits.

Managerial ownership has a significant negative effect on profitability. This condition occurs because the higher managerial ownership, the more opportunistic behavior of management will be, this will have a negative impact on company performance, so that profitability will decrease.

Leverage has a significant negative effect on profitability. This condition occurs because the greater this ratio indicates that the greater the capital structure that comes from debt is used to finance existing assets, so that the profit generated by the company will decrease.

Based on the results of the research that has been done, the advice given is that research must be able to contribute in the field of science, especially regarding Human Capital, Structural Capital, Customer Capital, Managerial Ownership, and Leverage on the profitability of manufacturing companies listed on the IDX in the 2015- 2017. The manager must be able to see what factors affect the company's profitability, so that they can manage their resources effectively in order to provide value to the company.

Some limitations in this study that still need to be used as material for further research revisions, namely this study can only explain the profitability of 34.60 percent, which is relatively small. This study can only explain the profitability of 34.60 percent, which is relatively small, for that further research can add independent variables, such as institutional ownership, GCG and liquidity, so that it can better explain profitability.

\section{REFERENCES}

Ahangar, R. G. (2011). The Relationship Between Intellectual Capital And Financial Performance: An Empirical Investigation In An Iranian Company. African Journal Of Business Management.

Aritonang, Q. A., Muharam, H., \& Sugiono. (2016). Pengaruh Intellectual Capital Terhadap Kinerja Keuangan. Jurnal Bisnis Strategi.

Badawi, A. (2018). "Pengaruh Good Corporate Governance Dan Intellectual Capital Terhadap Kinerja Keuangan Perusahaan Pada Perbankan Indonesia". . Program Doctoral Pascasarjana Universitas Mercubuana. 
Maharani, T., \& Fuad, K. (2020). The effect of human capital, structural capital, customer capital, managerial ownership, and leverage toward profitability of company. Journal of Advanced Multidisciplinary Research, 1 (1), 46-62. DOI: http://dx.doi.org/10.30659/JAMR.1.1.46-62

Barokah, S., Wilopo, \& Nuralam, I. P. (2018). Pengaruh Intellectual Capital Terhadap Financial Performance. Jurnal Administrasi Bisnis.

Bontis, N. (1998). Intellectual Capital: An Exploratory Study That Develops Measures And Models. Management Decision, 63-76.

Chariri, A., \& Ghozali, I. (2007). Teori Akuntansi. Semarang: Badan Penerbit Universitas Diponegoro.

Chen, Ming-Chin, Cheng, S. J., \& Hwang, Y. (2005). An Empirical Investigation Of The Relationship Between Intellectual Capital And Firm`S Market Value And Financial Performance. Journal Of Intellectual Capital.

Dewi, L. D. (2017). "Pengaruh Good Corporate Governance Dan Leverage Keuangan Terhadap Profitabilitas Pada Perusahaan Perbankan Di Bei". E- Jurnal Manajemen Unud, Vol. 6, No. 9, Hlm. 5032-5060.

Dragonetty, R. G. (1997). Intellectual Capital- Navigating In The New Business Landscape. New York University Press.

Effendi, M. A. (2009). The Power Of Corporate Governance: Teori Dan Implementasi. Jakarta: Salemba Empat.

Enekwe, C., \& Agu, C. \&. (2014). The Effect Of Financial Leverage On Financial Performance: Evidence Of Quoted Pharmaceutical Companies In Nigeria. Journal Of Economics And Finance, 17-25.

Fajarini, I. (2012). Pengaruh Intellectual Capital Terhadap Kinerja Keuangan Perusahaan . Jurnal Dinamika Akuntansi.

Ghozali, I. (2013). Aplikasi Analisis Multivariat Dengan Program Ibm Spss 23. Semarang : Badan Penerbit Universitas Diponegoro.

Hamidah, Purwati, E. S., \& Mardiyati, U. (2013). Pengaruh Corporate Governance Dan Leverage Terhadap Profitabilitas Bank Yang Go Public Di Indonesia Periode 2009-2012. Jurnal Riset Manajemen Sains Indonesia.

Haniffa, R. (2002). Social Reporting Disclosure: An Islamic Perspective. Indonesian Management \& Accounting Research, 128-146.

Hariyawan, B. E., \& Andayani. (2017). Pengaruh Struktur Modal, Ukuran, Profitabilitas Terhadap Nilai Perusahaan Dengan Pertumbuhan Sebagai Moderating. Jurnal Ilmu Dan Riset Akuntansi.

Hulland, B. A. (2001). Managing An Organizational Learning System By Aligning Stocks And Flows. Journal Of Management Studies.

Kartika, M. D. (2013). Pengaruh Intellectual Capital Terhadap Profitabilitas Perusahaan Perbankan Yang Terdaftar Di Bursa Efek Indpnesia Pada Tahun 2007-2011. Bussinessnaccounting Review, Vol.1, No.2, Hlm.14-25.

Kartikasari, Y. D. (2017). Pengaruh Good Corporate Governance Dan Modal Intelektual Terhadap Kinerja Keuangan Perusahaan Sektor Keuangan. Jurnal Profita.

Khalid, S. (2011). Financial Reforms And Dynamics Of Capital Structure Choice: A Case Of Publically Listed Firms Of Pakistan. Journal Of Management Research, 1-16.

Kuncoro, M. (2007). Metode Kuantitatif (Teori Dan Aplikasi Untuk Bisnis Dan Ekonomi). Yogyakarta: Upp Amp Ykpn.

Kuspinta, U. D. (2018). Pengaruh Intellectual Capital Terhadap Profitabilitas Perusahaan (Studi Pada Perusahaan Manufaktur Yang Terdaftar Di Bursa Efek Indonesia Periode Tahun 2014-2016). Jurnal Administrasi Bisnis.

Mardiyati Umi, P. S. (2013). Pengaruh Corporate Governance Dan Leverage Terhadap Profitabilitas Bank Yang Go Public Di Indonesia Periode 2009- 2012. Fakultas Ekonomi, Program Studi S1 Manajemen, Universitas Negeri Jakarta.

Noor, J. (2013). Penelitian Ilmu Manajemen. Jakarta: Kencana. 
Journal of Advanced Multidisciplinary Research

Vol. 1, No. 1, 2020, pp. 46-62

ISSN: $2723-6978$

http://jurnal.unissula.ac.id/index.php/JAMR

DOI: http://dx.doi.org/10.30659/JAMR.1.1.46-62

Pradwita, T. R. (2008). "Pengaruh Intellectual Capital Dan Struktur Kepemilikan Terhadap Kinerja Perusahaan". Skripsi. Surakarta: Fakultas Ekonomi Dan Bisnis Universitas Muhammadiyah.

Pratiwi, D. P. (2018). "Analisis Pengaruh Intellectual Capital Dan Karakteristik Keuangan Terhadap Kinerja Perusahaan Manufaktur". Skripsi. Surakarta: Fakultas Ekonomi Dan Bisnis Universitas Muhammadiyah .

Pulic, A. (1998). Meansuring The Performance Of Intellectual Potential In Knowledge Economy. Austria: Paper Presented At The 2nd Mcmaster And Managing Intellectual Capital By The Austrian Team For Intellecual Potential.

Putra, M. S. (2017). Pengaruh Human Capital, Structural Capital, Custumor Capital Dan Good Corporate Governance Terhadap Profitabilitas Perusahaan. E-Journal SI Ak, Vol. 7 No. 1

Rachmawati, D. (2012). Pengaruh Intellectual Capital Terhadap Return On Asset (Roa) Perbankan. Jurnal Nominal, Vol.1, 34-40.

Reza, W. G. (2015). Pengaruh Intellectual Capital Terhadap Profitabilitas Perusahaan Manufaktur Yang Terdaftar Di Bursa Efek Indonesia. Fakultas Ekonomi Universitas Negeri Yogyakarta.

Rousiita, S. (2012). Pengaruh Intellectual Capital Terhadap Profitabilitas, Produktifitas, Dan Penilaian Pasar Pada Perusahaan Yang Go Public Di Indonesia Pada Tahun 2005-2007. Universitas Tarumanagara.

Salehi, M., \& Manesh, N. B. (2012). A Study Of The Roles Of Firm And Country On Specific Determinates In Capital Structure: Iranian Evidence. International Management Review.

Sari. (2019). Pengaruh Current Ratio Dan Debt To Equity Ratio Terhadap Profitabilitas Dengan Intellectual Capital Sebagai Pemoderasi. E-Jurnal Akuntansi Universitas Udayana.

Sari, P. R., \& Dwirandra, A. A. (2019). Pengaruh Current Ratio Dan Debt To Equity Ratio Terhadap Profitabilitas Dengan Intellectual Capital Sebagai Pemoderasi. E-Jurnal Akuntansi.

Sartono, R. A. (2010). Manajemen Keuangan. Yogyakarta:Bpfe Ugm. Sawarjuwono, T., \& Kadir, A. P. (2003). Intellectual Capital: Perlakuan,

Pengukuran Dan Pelaporan (Sebuah Library Research). Jurnal Akuntansi Dan Keuangan.

Sjahrial, D. (2009). Manajemen Keuangan. Edisi Tiga. Jakarta: Mitra Wacana Media.

Starovic, D. D. (2004). Understanding Corporate Value : Managing And Reporting Intellectual Capital. Chartered Institute Of Management Accountants.

Sugiyono. (2016). Metode Penelitian Manajemen. Bandung: Alfabeta.

Suryani, S. (2011). Analisis Pengaruh Financing To Deposit Ratio (Fdr) Terhadap Profitabilitas Perbankan Syariah Di Indonesia. Jurnal Penelitian Sosial Keagamaan.

Syamsudin, L. (2001). Manajemen Keuangan Perusahaan, Edisi Baru. Jakarta: Pt. Raja Grafindo .

Ulum, I. (2009). Intellectual Capital. Yogyakarta: Ghara Ilmu.

Wilopo R, T. D. (2011). Pengaruh Good Corporate Governance(Gcg) Terhadap Profitabilitas Dan Kinerja Saham Perusahaan Perbankan Yang Tercatat Di Bursa Efek Indonesia. Pascasarjana Stie Perbanas Surabaya.

Zarkasyi, W. (2008). Good Corporate Governance Pada Badan Usaha Manufaktur, Perbankan, Dan Jasa Keuangan Lainnya. Bandung: Alfabeta. 